\title{
Molecular Basis of Hereditary C3 Deficiency
}

Marina Botto, Kok Yong Fong, Alex K. So, Andrew Rudge, and Mark J. Walport

Rheumatology Unit, Department of Medicine, Royal Postgraduate Medical School, London, W12 0NN, United Kingdom

\begin{abstract}
Hereditary deficiency of complement component $\mathrm{C} 3$ in a 10-yr-old boy was studied. C3 could not be detected by RIA of serum from the patient. Segregation of $\mathrm{C3} S$ and $\mathrm{C} 3 \mathrm{~F}$ allotypes within the family confirmed the presence of a null gene for $\mathrm{C} 3$, for which the patient was homozygous. 30 exons have been characterized, spanning the entire $\beta$ chain of $\mathrm{C} 3$ and the $\alpha$ chain as far as the $C 3 d$ region. Sequence analysis of the exons derived from the $\mathrm{C} 3$ null gene showed no abnormalities in the coding sequences. A GT-AT mutation at the $5^{\prime}$ donor splice site of the intervening sequence 18 was found in the $\mathrm{C} 3$ null gene. Exons 17-21 were amplified by the polymerase chain reaction (PCR) from first-strand cDNA synthesized from mRNA obtained from peripheral blood monocytes stimulated with LPS. This revealed a 61-bp deletion in exon 18, resulting from splicing of a cryptic $5^{\prime}$ donor splice site in exon 18 with the normal $3^{\prime}$ splice site in exon 19 . This deletion leads to a disturbance of the reading frame of the mRNA with a stop codon 17 bp downstream from the abnormal splice in exon 18. His parents had both the normal and abnormal C3 mRNA and were shown to be heterozygous for this mutation by sequence analysis of genomic DNA amplified by PCR. Similar splice mutants have previously been reported in the $\beta$-globin, phenylalanine hydroxylase, and porphobilinogen deaminase genes. This mutation is sufficient to cause the deficiency of $\mathrm{C} 3$ in the patient. (J. Clin. Invest. 1990. 86:1158-1163.) Key words: complement $3 \cdot$ alternative splicing $\bullet$ immune deficiency $\bullet$ RNA splicing
\end{abstract}

\section{Introduction}

Complement protein $\mathrm{C} 3$ is the major component of the complement system in plasma $(\sim 1 \mathrm{~g} /$ liter $) . \mathrm{C} 3$ is synthesized mainly by the liver and in small amounts by activated monocytes and macrophages. It is produced as a single polypeptide of $185 \mathrm{kD}$, pro- $\mathrm{C} 3$, which is then processed by proteolysis to yield the mature protein, consisting of two disulfide-linked subunits, $\alpha$ and $\beta$, of 110 and $75 \mathrm{kD}$, respectively. The $\mathrm{C} 3$ gene is located on human chromosome 19 (1). Cloning of the C3 gene from cDNA revealed that the precursor molecule consists of 1663 amino acids, and that it has significant sequence homology to $\alpha 2$-macroglobulin and C4 (2). The full organization of the human $\mathrm{C} 3$ gene has recently been defined $(3,4)$, showing that this gene spans $\sim 41 \mathrm{~kb}$ and consists of 41 exons.

Address reprint requests to Dr. Mark Walport, Rheumatology Unit, Royal Postgraduate Medical School, Hammersmith Hospital, Du Cane Road, London W12 0NN, United Kingdom. 990

Received for publication 5 April 1990 and in revised form 24 May

J. Clin. Invest.

(c) The American Society for Clinical Investigation, Inc.

$0021-9738 / 90 / 10 / 1158 / 06 \$ 2.00$

Volume 86, October 1990, 1158-1163
Inherited deficiency of $\mathrm{C} 3$ has been described in man, dogs, and guinea pigs. C3-deficient dogs show an autosomal codominant pattern of inheritance, and animals heterozygous for the deficiency state have $\sim 50 \%$ of the mean $\mathrm{C} 3$ concentration found in normal dogs (5). The study of human subjects with hereditary $\mathrm{C} 3$ deficiency provides the best evidence for the physiological activities of the complement system in vivo. 15 such individuals (6-15) have been described, 12 of whom have suffered from recurrent pyogenic infections, which emphasizes the important physiological role of $\mathrm{C} 3$ as an opsonin for bacteria. Two patients have developed mesangiocapillary glomerulonephritis $(7,10)$, and three hematuria and/or proteinuria (14). It has been proposed that this association with nephritis is due to failure of a second physiological activity of the complement system, that of promoting the disposal of immune complexes to the mononuclear phagocytic system (16).

There is evidence for genetic heterogeneity in the molecular basis of C3 deficiency. Small amounts of circulating C3 were identified in the sera from some patients with $\mathrm{C} 3$ deficiency (9), but in others no C3 was detected at all (17). In this paper, we report the molecular basis for $\mathrm{C} 3$ deficiency in a patient with homozygous deficiency. We found that an unusual RNA splicing abnormality results in a deletion of 61 nucleotides with a stop codon 17 bases downstream of the abnormal splice site.

\section{Methods}

Complement assays. Antigenic concentrations of $\mathrm{C} 1 \mathrm{q}, \mathrm{C} 2, \mathrm{C} 3$, and $\mathrm{C} 4$ were measured by single radial immunodiffusion. $\mathrm{CH}_{50}$ was estimated by a modification of the method of Mayer (18). Alternative pathway and factor $B$ activities were measured by a hemolytic plate assay as described (18). Nephritic factor was measured as previously described (19). An RIA was developed for quantitation of $\mathrm{C} 3$ using an mAb against C3d (clone 3; gift of Prof. P. J. Lachmann, Medical Research Council, Molecular Immunopathology Unit, Cambridge). The antibody, at $10 \mu \mathrm{g} / \mathrm{ml}$ in PBS, $10 \mathrm{mM} \mathrm{NaN}_{3}, 0.05 \%$ Tween-20, pH 7.3 was coated on wells of polystyrene microtitre plates (Dynatech, Billingshurst, Sussex, England). The plates were blocked with PBS, $10 \mathrm{mM}$, $\mathrm{NaN}_{3}, 0.05 \%$ Tween-20, $1 \%$ BSA, and then incubated with dilutions of sera. Polyclonal affinity-purified goat anti-C3 antibody was labeled with ${ }^{125} \mathrm{I}$ to a specific activity of $1-2 \mu \mathrm{Ci} / \mu \mathrm{g}$ and used to probe the microtiter plates at a final concentration of $20 \mu \mathrm{g} / \mathrm{ml}$. The sensitivity of the assay was $60 \mathrm{ng} \mathrm{C} 3 / \mathrm{ml}$. Purified C3 for assays of reconstitution of hemolytic activity of the patient's serum was kindly donated by Prof. G. D. Ross (University of North Carolina, Chapel Hill). C3 allotyping was performed by high-voltage agarose gel electrophoresis using a modified version of the method of Teisberg (20).

Preparation and analysis of genomic DNA. Genomic DNA was isolated from whole blood. $10 \mu \mathrm{g}$ of DNA was digested to completion with eight different restriction enzymes (Bam HI, Pst I, Taq I, Eco RI, Hind III, Bgl II, Pvu II, Msp I) (Gibco Bethesda Research Laboratories, Uxbridge, Middlesex), and electrophoresed on a $0.8 \%$ agarose gel and Southern blotted (21) onto Hybond-N membranes (Amersham International, Amersham, England). The filters were hybridised with a cDNA probe for C3, pC3.11 (22), (kindly provided by Dr. G. Fey, Scripps Clinic, La Jolla, CA), which was labeled by the random primer 
method (23). The filters were then washed to high stringency $(0.2 \times$ $\mathrm{SSC}, 0.1 \%$ SDS at $65^{\circ} \mathrm{C}$ ) and exposed to film for $3-7 \mathrm{~d}$ at $-70^{\circ} \mathrm{C}$.

Preparation of $m R N A$ from monocyte-derived macrophages and Northern blotting. Mononuclear cells were isolated from $30-40 \mathrm{ml}$ of peripheral blood by centrifugation on Lymphoprep (Nycomed, Oslo, Norway). The mononuclear fraction was resuspended in serum-free Iscove's modified medium (Gibco-Biocult, Paisley, Scotland) and adhered for $2 \mathrm{~h}$ in 24-well tissue-culture trays and washed to remove non-adherent cells. Monocytes were cultured in Iscove's medium supplemented with $10 \%$ heat-inactivated autologous serum for $5 \mathrm{~d}$ and then stimulated for $48 \mathrm{~h}$ with LPS (Sigma Chemical Co., Dorset, England) at a concentration of $5 \mu \mathrm{g} / \mathrm{ml}$ in medium alone. mRNA was harvested using the guanidinium isothiocyanate/cesium chloride method (24) and Northern blot analysis was performed using the pC3.11 cDNA clone as a probe. Liver mRNA was used as a positive control. The same filters were also hybridized with an $\alpha$-tubulin probe (25) as an RNA control.

Construction and screening of genomic library. Genomic DNA isolated from a B-lymphoblastoid cell line, transformed by Epstein-Barr virus, from the patient was partially digested with $\operatorname{Sau} 3 \mathrm{~A} I$, and fragments were separated by electrophoresis in a $0.6 \%$ low-melting point agarose gel (Bethesda Research Laboratories, Gaithersburg, MD). DNA fragments sized between 10 and $23 \mathrm{~kb}$ were isolated and ligated to lambda EMBL-3 vector, and packaged in vitro (26). 1.5 million recombinants were screened using two probes, pC3.11 and pC3.59 (22), spanning the full length of the human C3 cDNA. Recombinant phage from large-scale lysates was purified by equilibrium centrifugation in cesium chloride density gradients and DNA was extracted from phage particles (24)

Restriction mapping and DNA sequencing. Restriction maps of the lambda clones were obtained after single and double digests with restriction enzymes and Southern blot analysis using the C3 cDNA clones as probes. Specific exon-encoding genomic fragments were subcloned into the plasmid PUC 18 for detailed analysis. DNA sequencing was performed by the dideoxy-termination method (27) after subcloning of DNA fragments into M13mp8 or mp9, using Sequenase (United States Biochemical Corp., Cleveland, $\mathrm{OH}$ ).

Polymerase chain reaction $(P C R)$ amplification of genomic DNA. Two 21-mer oligonucleotides (5'CGTTTCCCGAAGTGAGTTCCC $3^{\prime}$, nucleotide positions 2,343-2,363, named Oligo EX18, and 5' ATGCTGACAGCCAGAATCTCC 3 ' complementary to nucleotide positions 2,466-2,486, Oligo EX19) (22) were chemically synthesized. These were used as primers in PCR to amplify $1.0 \mu \mathrm{g}$ of genomic DNA, using 1 unit of Taq polymerase (Perkin-Elmer Cetus Corp., Norwalk, CT). 30 cycles of the reaction were performed at $94^{\circ} \mathrm{C}$ for $2 \mathrm{~min}, 56^{\circ} \mathrm{C}$ for $2 \mathrm{~min}$, and $72^{\circ} \mathrm{C}$ for $2 \mathrm{~min}$. The amplified DNA was subcloned into Sma I-digested M13mp8, and sequenced as described above.

cDNA synthesis and PCR amplification. First-strand cDNA synthesis was performed as reported (28) using $2 \mu \mathrm{g}$ of total mRNA obtained from monocytes-derived macrophages stimulated with LPS, as previously described, from the $\mathrm{C} 3$-deficient patient, his mother and a normal subject. Amplification of cDNA was then carried out using PCR by addition of $2.5 \mathrm{U}$ of Taq polymerase, $8 \mu \mathrm{l}$ DMSO, $8 \mu \mathrm{l}$ of PCR supplement buffer $\left(500 \mathrm{mM}\right.$ Tris pH $8.3,167 \mathrm{mM} \mathrm{NH}_{4} \mathrm{SO}_{4}, 100 \mathrm{mM}$ $\beta$-mercaptoethanol), $100 \mathrm{ng}$ of each primer Oligo EX17, 5 CTGCGGCGGCAGCACGCGCGG 3', corresponding to positions 2,260-2,280 and Oligo EX21, 5' GGTGGCCAGGCTGCAGAAGGC $3^{\prime}$, complementary to positions $2,671-2,691$. The samples were amplified by 30 cycles of heat denaturation at $94^{\circ} \mathrm{C}$ for $1 \mathrm{~min}$, annealing at $50^{\circ} \mathrm{C}$ for $1 \mathrm{~min}$, and primer extension at $72^{\circ} \mathrm{C}$ for $1 \mathrm{~min}$. The amplified product was separated on $2 \%$ agarose gel, electroeluted, precipitated with ethanol, subcloned in Sma I-digested M13mp8 and sequenced as described above. The same method was applied to amplify and sequence the $\beta$ chain of the cDNA using two pairs of oligos: Oligo EX 1, 5 ' GCTGCTCCTGCTACTAACCCA 3', nucleotide positions 87-107, and Oligo EX4, 5' TAGCAGCTTGTGGTTGAC 3', complementary to nucleotide positions 514-531; Oligo EX3, 5' ATCCCAGCCAACAGGGAG $3^{\prime}$, nucleotide positions $328-345$, and Oligo EX8, $5^{\prime}$
AAAGGCAGTTCCCTCCACTTT 3', complementary to positions 850-870. Part of the C3d region was amplified by using Oligo EX28, 5 ATGCTCTGGCCCAGATGG 3 ', corresponding to nucleotides 3,641-3,658, and Oligo EX30, 5' TCCTGGTGGTCAGGGGCG 3', complementary to 3,915-3,932. PCR-products obtained with EX17 and EX21 (exon 17-21) from the normal individual, the patient and his mother were electrophoresed on a $2 \%$ agarose gel and Southern blotted. The filter was probed overnight with Oligo EX19 kinased with $\left[\gamma^{32} \mathrm{P}\right]$ ATP to a specific activity of $10^{8} \mathrm{cpm} / \mu \mathrm{g}$. The density of the autoradiographic bands was then quantified by scanning densitometry (Joyce-Loebl, Chromoscan III, Gateshead, England).

Case report. The patient is a 10 -yr-old boy who suffered from recurrent attacks of otitis media, and one febrile convulsion during the first $3 \mathrm{yr}$ of life. Between 5 and 8 yr of age he suffered from $>20$ episodes of rash affecting his face, forearms, and hands. The eruption consisted of discrete, raised, erythematous plaques some of which resembled the target lesions of erythema multiforme. The lesions over his wrists were accompanied by marked subcutaneous edema and were extremely tender. The rash and swelling spontaneously healed after about a week on each occasion. Attacks were usually preceded by an upper respiratory tract infection, and a group A $\beta$-hemolytic Streptococcus was isolated from his throat during two episodes. His growth and milestones were normal. Systemic examination was repeatedly normal with no hypertension, urinary deposit, or proteinuria.

The patient's parents are consanguineous and share a common greatgrandparent. A distant cousin of the patient died of Bright's disease in 1942. There is no other family history of nephritis or of recurrent infectious diseases.

\section{Results}

Complement investigations and family study. The $\mathrm{CH}_{50}$ of the patient was $42 \mathrm{U} / \mathrm{ml}$ (normal control pool 2,512 U/ml). Alternative pathway activity was $<10 \%$ of normal pooled serum (NHS). Functional factor B activity was $112 \%$ of NHS. The antigenic concentrations of the following complement proteins were: $\mathrm{Clq} 75 \%, \mathrm{C} 257 \%, \mathrm{C} 455 \%$. No C3d was detected in the patient's serum and assay for $\mathrm{C} 3$ nephritic factor was negative. C3 was not detected using a radioimmunoassay with a sensitivity of $60 \mathrm{ng} \mathrm{C} 3 / \mathrm{ml}$. The addition of purified $\mathrm{C} 3$ to the patient's serum to a final concentration of $1 \mathrm{~g} /$ liter restored the $\mathrm{CH}_{50}$ to $2,010 \mathrm{U} / \mathrm{ml}$.

The results of $\mathrm{C} 3$ allotyping studies and measurement of serum C3 concentrations of the family members are shown in Fig. 1, which demonstrate the existence of a null $\mathrm{C} 3$ gene $\left(C 3^{*} Q O\right.$ [quantity 0$]$ ) within the family. The patient's maternal grandfather was C3 FS and his grandmother C3 S. Two of their children were allotyped: the patient's mother who was C3 S and her brother, who was $\mathrm{C} 3 \mathrm{~F}$ alone. This latter individual must therefore have inherited a $C 3^{*} Q 0$ allele from his mother, whose genotype must therefore be $C 3 S^{*} Q 0$, and the segregation of this $C 3^{*} Q 0$ allele was confirmed by measurements of antigenic levels of $\mathrm{C} 3$ amongst the family members (Fig. 1).

Genomic organization of the $C 3$ null gene. Southern blot analysis of DNA from the patient and family members after digestion with eight different restriction enzymes and using a C3 cDNA probe showed no structural difference between the C3 null gene and normal allelic variants (data not shown). We therefore constructed and screened a genomic library derived from the patient using pC3.11 and pC3.59 as probes, and isolated five positive clones ranging in size from 9 to $17 \mathrm{~kb}$. Mapping of these genomic clones showed that they spanned the $\beta$ chain, from amino acid 259, to the $3^{\prime}$ end of the $\alpha$ chain.

The genomic organization of the $\mathrm{C} 3$ gene was obtained by 

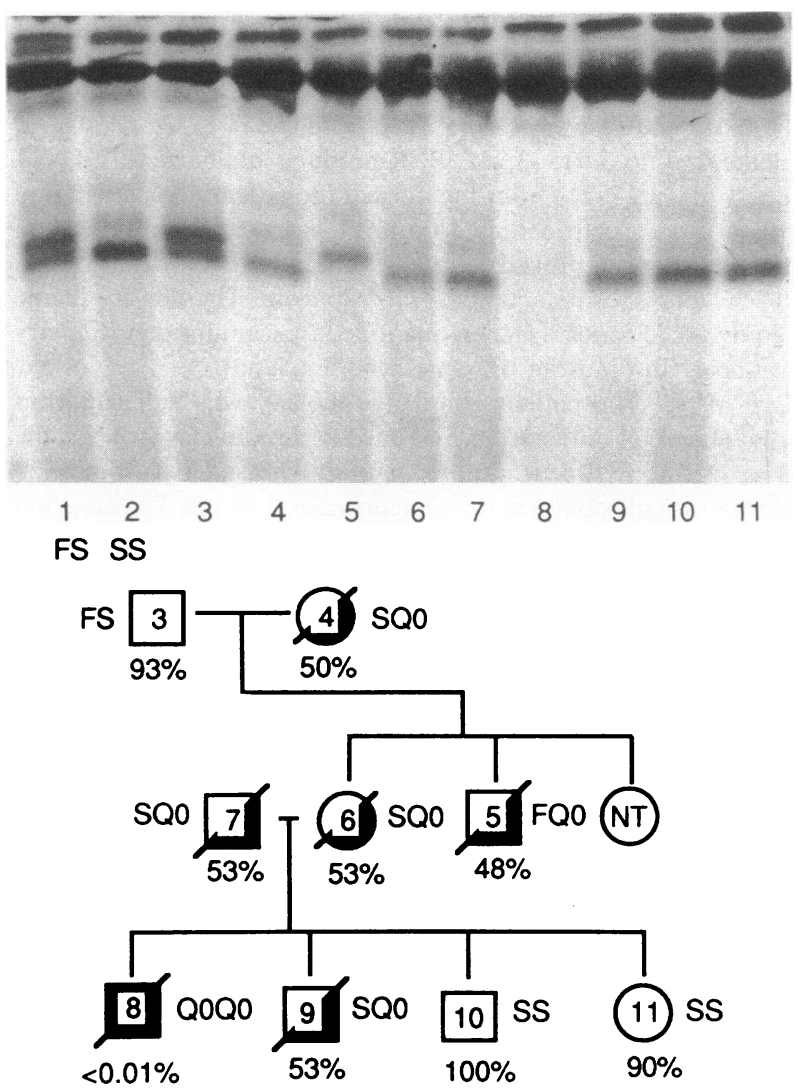

Figure 1. C3 allotype analysis and family tree. (Top) agarose gel electrophoresis of sera from family members to demonstrate the C3 S and $\mathrm{C} 3 \mathrm{~F}$ polymorphism. Samples 1 and 2 were controls, whereas samples 3-11 were obtained from the family members. $F$ and $S$ refer to the fast and slow bands of $\mathrm{C} 3$ respectively. The family tree is shown at the lower half of the figure. Individuals with half of the normal $\mathrm{C} 3$ concentration are indicated with half blackened symbols; the propositus (no. 8) is shown as a fully blackened square. $N T$, not tested. $F, S$ and $Q 0$ are the inferred $\mathrm{C} 3$ genotypes in the family members.

sequencing of subcloned DNA fragments, and the exon-intron organization was compared with the published C3 cDNA sequence (22). A total of 23 exons have been analyzed spanning from exon 8 , corresponding to nucleotide 834 of $\mathrm{C} 3$ cDNA (22), to exon 30 , nucleotide 4,029 . Sequences distal to these exons were not fully characterized. From comparison with published cDNA, no differences in the coding region of the $\mathrm{C} 3$ null gene (from exon 8-30) were found.

$A 5^{\prime}$ donor splice site mutation from $G T$ to $A T$ in the $C 3$ null gene. Sequencing of the $\mathrm{C} 3$ null gene revealed a G-A transition in the $5^{\prime}$ donor splice site of intervening sequence (IVS) 18 (3). This alters the consensus GT dinucleotide to AT (Fig. 2). In order to verify that this finding was not caused by a cloning artefact, two 21-mer oligonucleotides, EX18 and EX19, complementary to sequences in exons 18 and 19, were constructed and used to amplify genomic DNA by PCR. Amplified DNAs were sequenced, and the results showed that both parents of the patient were heterozygous for the normal and abnormal $5^{\prime}$ splice sequence. Sequences over the same region from two normal individuals showed the normal $5^{\prime}$ donor splice site consensus sequence of GT. All the other $225^{\prime}$ exon-intron boundaries were identical to the consensus sequences found in
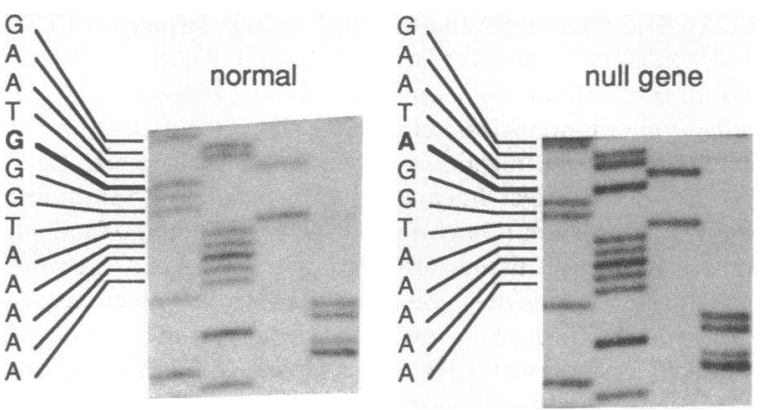

Figure 2. Sequence of splice site of IVS 18. Autoradiograph showing sequences obtained from genomic DNA amplified by PCR spanning the 5 ' donor splice site of IVS 18. Sequencing tracks: G-A-T-C from left to right. The single base mutation between the normal $\mathrm{C} 3$ gene and the null $\mathrm{C} 3$ gene is indicated in bold. This sequence is read from the bottom of the figure.

the normal $\mathrm{C} 3$ gene (3); the $233^{\prime}$ intron-exon boundary dinucleotides were all AG.

Abnormal splicing of the $C 3$ null gene. Preliminary studies by the technique of Northern blotting of C3 mRNA obtained from peripheral blood monocytes stimulated by LPS suggested an absence of $\mathrm{C} 3$ mRNA production in the patient. However, these results were not conclusive due to difficulties with obtaining sufficient peripheral blood to prepare large numbers of monocytes. We therefore took the following approach to analyze C3 mRNA in the patient. We performed a first strand cDNA synthesis and we used this as template for PCR amplification of target sequences encoding different regions of the C3 molecule.

Amplification of the region spanning exons 17-21 (using Oligos EX17 and EX21 as primers) from the patient generated a product that was smaller in size than that found in the normal subject (Fig. 3). Both the PCR products were detected from the cDNA of the patient's mother, who was shown to be heterozygous for the splice site mutation at the genomic level. A ratio of $\sim 4: 1$ between the normal and the abnormal message was calculated by scanning with a densitometer the autoradiograph of Southern blot probed with Oligo EX19, corresponding to a region in the middle of exon 19 (Fig. 4). On sequencing the abnormal fragment from the patient, a 61-nucleotide deletion of the normal cDNA sequence was found (from nucleotides 2,354-2,414) and results in the joining of part of exon 18 to exon 19. This mRNA sequence is out of the normal translation frame distal to the abnormal splice and generates a stop codon (TGA) 17 bp downstream in exon 19 (Fig. 5). A cryptic donor splice consensus sequence (GTGAGT) was identified within exon $18,5^{\prime}$ to the site of the abnormal splice. Amplification of two other regions of the cDNA $5^{\prime}$ and $3^{\prime}$ to the splice site mutation (spanning exons 3-8 in the $\beta$ chain and exons $28-30$ in the $\alpha$ chain) generated products of identical size in both the patient and the normal subject (Fig. 3).

We also amplified and sequenced the cDNA of the $\mathrm{C} 3$ null gene from the signal peptide to amino acid 263 to verify the possibility of further mutation upstream from the splice site mutation. The size of PCR-products were 445 (Oligos EX1 and EX4) and 543 bp (Oligos EX3 and EX8), identical to the normal subjects. No differences in the sequences of these fragments were found when compared with the published cDNA. 


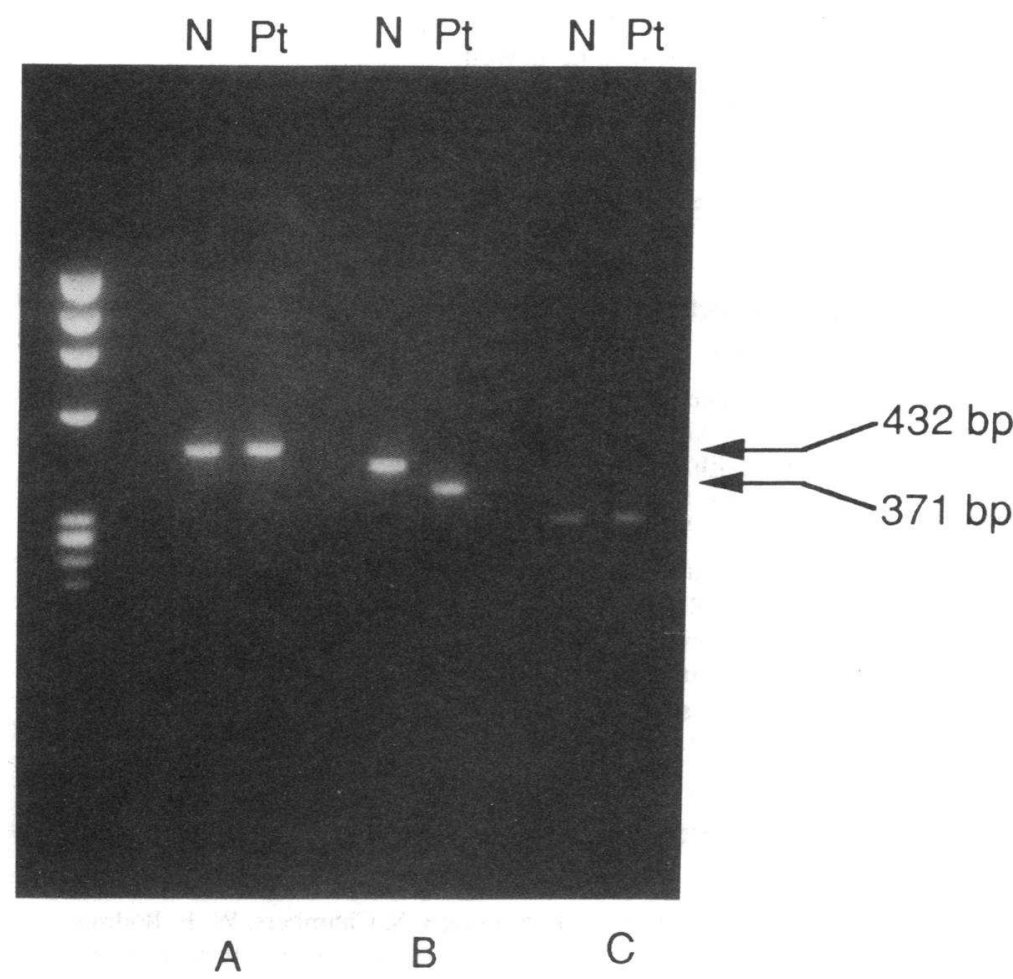

Figure 3. Agarose gel electrophoresis of PCR products. Amplified products from C3 cDNA derived from LPSstimulated monocytes were reamplified before electrophoresis on a $2 \%$ agarose gel. The conditions for PCR were as stated in the text. The paired tracks A, B, C represent regions spanning exons 3-8 in the $\beta$ chain, exons $17-21$ over the mutant splice region and exons $28-30$ in the C3d region, respectively. Lanes labeled $N$ and $P t$ represent samples from a normal individual and from the patient, respectively. Hae III-digested bacteriophage $\phi \mathrm{X}$ 174 was run as size standards. Paired tracks B showed bands of $432(N)$ and $371 \mathrm{bp}(P t)$ in sizes, revealing a difference of 61 nucleotides in the coding region. The primers were Oligos EX3 and EX8 (track $A$ ), Oligos EX17 and EX21 (track $B$ ), Oligos EX28 and EX30 (track $C$ ). Both PCR products in track B were subsequently sequenced.
This finding confirmed that the splice site transition at IVS 18 is the cause of the deficiency, although we cannot exclude the slight possibility that additional sequence abnormalities $3^{\prime}$ to exon 30 may also exist.

\section{Discussion}

Our patient suffered from frequent pyogenic infections of the upper respiratory tract during early childhood and went on to develop a rash resembling erythema multiforme following infection. Investigations led to the discovery of $\mathrm{C} 3$ deficiency. The history of consanguinity within his family suggested the
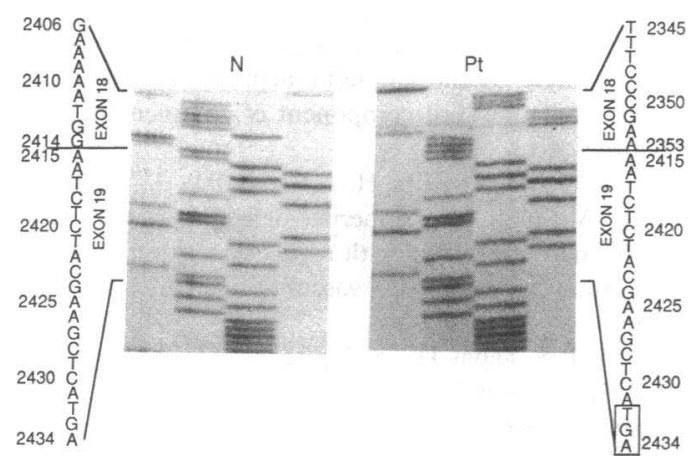

Figure 4. Autoradiograph of sequences from exons 18 and 19. Amplified DNA obtained from PCR of C3 cDNA were cloned into M13mp8 cleaved with Sma I and sequenced as described in the text. The autoradiograph is read from the top downwards and the alphabets $\mathrm{G}, \mathrm{A}, \mathrm{T}, \mathrm{C}$, refer to nucleotides guanine, adenine, thymine and cytosine respectively. Sequences from the patient's amplified DNA showed a 61-nucleotide deletion and a stop codon, TGA (shown within the rectangle), 17 bases downstream. Numbering of the nucleotides is according to the published C3 cDNA (22). possibility of homozygosity for an inherited condition and the presence of a null allele for $\mathrm{C} 3$ was confirmed in this family by analysis of the segregation of $\mathrm{C} 3$ allotypes.

No C3 protein was detected using a radioimmunoassay with a sensitivity of $60 \mathrm{ng} / \mathrm{ml}$. It should be noted that a previous study (9) demonstrated C3 concentrations between 17 and $58 \mathrm{ng} / \mathrm{ml}$ in the sera of three other unrelated caucasoid C3-deficient patients, levels that are below the detection limit of the present assay. However the studies of the gene structure and mRNA expression in our patient suggest the presence of absolute deficiency of functional C3. Using Northern blot analysis we were unable to detect any C3 mRNA in the LPSstimulated monocytes from our patient, probably due to the insufficient sensitivity of this technique. No gross structural alterations in the $\mathrm{C} 3$ gene were found by Southern blot analysis using a C3 cDNA probe and therefore we proceeded to

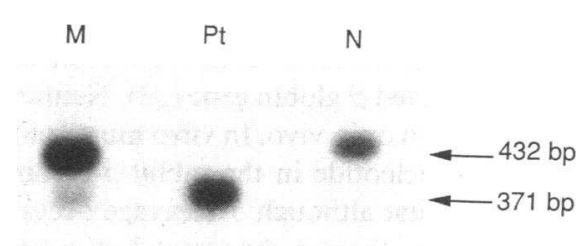

Figure 5. Autoradiograph showing normal- and abnormal-sized amplified DNA from C 3 cDNA. Lane $A$ is from a normal individual, lane $B$ from the patient, and lane $C$ from the patient's mother, who is heterozygous for the mutation. The strong signals from Lanes $A$ and $B$ were due to reamplification of the initial PCR products before electrophoresis. They act as size markers and positive controls. Lane CSDNA was electrophoresed after the initial amplification and illustrate the predominance of the normal allele over the abnormal allele. Primers used in the PCR were EX17 and EX21. The filter was probed with Oligo EX19 kinased with [ $\gamma^{32}$ P]ATP and exposed to film. 
analyse directly the sequence of the gene. 30 exons from the $\mathrm{C} 3$ null gene were sequenced and no abnormality was detected. However, a mutation of the $5^{\prime}$ donor splice consensus sequence from GT to AT was identified in IVS 18, and further sequence analysis of amplified DNA from his parents showed that they were both heterozygous for this mutation. As the parents are second cousins, it is likely that they both carry an identical defective $\mathrm{C} 3$ gene, for which the patient is homozygous. As C3 synthesis from hepatic tissue could not be investigated in our patient, we used the PCR to detect very small amounts of abnormal C3 mRNA in LPS-stimulated monocytes to determine the consequence of the splice mutation. Amplification of the region spanning the splice mutation resulted in a product smaller in size than the wild type message. Sequence analysis of this fragment revealed the presence of a deletion of 61 nucleotides from exon 18 that also generates a stop codon, TGA, 17 nucleotides downstream. This unusual, out of frame, deletion is probably due to the fact that the spliceosome complex does not bind to the mutant 5 ' splice site but interacts with a cryptic $5^{\prime}$ donor splice site consensus sequence located in the middle of exon 18 , cleaves at this point and results in the joining of part of exon 18 to exon 19. To our knowledge, this finding is the first example of splice site abnormality in which the aberrant splice event occurs in the coding region preceding the mutation, making use of an intact splice site that is usually completely ignored. Therefore, with this abnormality in the C 3 mRNA in our patient, we are confident that sequences $3^{\prime}$ to exon 18 will not contribute to $\mathrm{C} 3$ deficiency.

There are several known examples of molecular pathology following a mutation in the consensus GT dinucleotide donor splice site at the $5^{\prime}$ boundary between exons and introns (29, $30)$. Such mutations have been identified at the $5^{\prime}$ end of IVS 1 (31) and IVS $2(31-33)$ in the $\beta$-globin gene, causing $\beta^{\circ}$-thalassaemia; in the phenylalanine hydroxylase gene, causing phenylketonuria (34); and in the porphobilinogen deaminase gene, causing acute intermittent porphyria (35).

The effects of naturally occurring mutations in the canonical GT 5' donor splice junction dinucleotide on RNA processing and subsequent protein expression are variable. In phenylketonuria there is a GT-AT mutation at the $5^{\prime}$ donor splice site of exon 12. The transfected abnormal phenylalanine hydroxylase gene directed aberrant splicing of exon 11 to exon 13 of precursor RNA. This resulted in production of a dysfunctional, unstable, and truncated protein lacking 52 amino acids (36). Two abnormal RNA transcripts were produced in vitro in the case of the GT-AT mutant at the $5^{\prime}$ donor splice site of IVS 2 of the cloned and transfected $\beta$-globin gene (33). Neither encoded $\beta$-globin protein in vitro or in vivo. In vitro mutations of the $5^{\prime}$ donor splice site dinucleotide in the rabbit $\beta$-globin gene from GT to AT showed that although $5^{\prime}$ cleavage occurs correctly with reduced efficiency, there is abnormal $3^{\prime}$ cleavage and accumulation of lariat intermediates (37).

The presence of a small amount of haemolytic activity measured by $\mathrm{CH}_{50}$ (1.6\% of normal) may be due to a small amount of $\mathrm{C} 5$ cleavage by $\mathrm{C} 42$ occurring in the absence of $\mathrm{C} 3$ as previously suggested by Kitamura (17). It seems clear that this patient has an absolute deficiency of $\mathrm{C} 3$ on the basis of the evidence presented here. It is therefore of interest that he is extremely fit and has attained the normal physical and intellectual milestones of a 10-yr-old boy. Apart from repeated upper respiratory tract infections and associated rashes as a young child, largely controlled by the administration of prophylactic antibiotics, he is well.

In conclusion, we have presented a molecular explanation for a case of total deficiency of C3. Studies of such patients provide the clearest opportunity to ascertain the physiological activity of $\mathrm{C} 3$ in vivo.

\section{Acknowledgments}

We would like to thank Dr. J. J. Cream (Charing Cross Hospital, London) for kindly referring this patient, Dr. D. Crawford (RPMS, Hammersmith Hospital, London) for preparation of the EBV-transformed B cell line and Prof. L. Luzzatto for helpful discussions and advice.

A.K.S. is supported by the Wellcome Trust, and K. Y. Fong by the Arthritis and Rheumatism Council, M. Botto is in receipt of a research fellowship from the University of Verona. These studies were supported by grants from the Arthritis and Rheumatism Council and the Wellcome Trust.

\section{References}

1. Whitehead, A. S., E. Solomon, S. Chambers, W. F. Bodmer, S. Povey, and G. Fey. 1982. Assignment of the structural gene for the third component of human complement to chromosome 19. Proc. Natl. Acad. Sci. USA. 79:5021-5025.

2. Sottrup-Jensen, L., T. M. Stepanik, T. Kristensen, P. B. Lonblad, C. M. Jones, D. M. Wierzbicki, S. Magnusson, H. Domdey, R. Wetsel, A. Lundwall, B. F. Tack, and G. H. Fey. 1985. Common evolutionary origin of $\alpha 2$-macroglobulin and complement components C3 and C4. Proc. Natl. Acad. Sci. USA. 82:9-13.

3. Fong, K. Y., M. Botto, M. J. Walport, and A. K. So. 1990. Genomic organisation of human complement component C3. Genomics. 7:579-586.

4. Barnum, S. R., P. Amiguet, F. Amiguet-Barras, G. H. Fey, and B. F. Tack. 1989. Complete intron/exon organization of DNA encoding the $\alpha^{\prime}$ chain of human C3. J. Biol. Chem. 264:8471-8474.

5. Winkelstein, J. A., J. P. Johnson, K. C. O'Neil, and L. C. Cork. 1986. Dogs deficient in C3. Prog. Allergy. 39:159-168.

6. Alper, C. A., H. R. Colten, F. S. Rosen, A. R. Rabson, G. M. MacNab, and J. S. S. Gear. 1972. Homozygous deficiency of C3 in a patient with repeated infections. Lancet. ii:1179-1181.

7. Berger, M., J. E. Balow, C. B. Wilson, and M. M. Frank. 1983. Circulating immune complexes and glomerulonephritis in a patient with congenital absence of the third component of complement. $N$. Engl. J. Med. 308:1009-1013.

8. Roord, J. J., M. Daha, W. Kuis, H. A. Verbrugh, J. Verhoef, B. J. M. Zegers, and J. W. Stoop. 1983. Inherited deficiency of the third component of complement associated with recurrent pyogenic infections, circulating immune complexes, and vasculitis in a Dutch family. Pediatrics. 71:81-87.

9. Davis, A. E. III, J. S. Davis IV, A. R. Rabson, S. G. Osofsky, H. R. Colten, F. S. Rosen, and C. A. Alper. 1977. Homozygous C3 deficiency: detection of $\mathrm{C} 3$ by radioimmunoassay. Clin. Immunol. Immunopathol. 8:543-550.

10. Borzy, M. S., A. Gewurz, L. Wolff, D. Houghton, and E. Lovrien. 1988. Inherited $C 3$ deficiency with recurrent infections and glomerulonephritis. AJDC (Am. J. Dis. Child.) 142:79-83.

11. Osofsky, S. G., B. H. Thompson, T. F. Lint, and H. Gewurz. 1977. Hereditary deficiency of the third component of complement in a child with fever, skin rash, and arthralgias: response to transfusion of whole blood. J. Pediatr. 90:180-186.

12. Sano, Y., H. Nishimukai, H. Kitamura, K. Nagaki, S. Inai, Y. Hamasaki, I. Maruyama, and A. Igata. 1981. Hereditary deficiency of 
the third component of complement in two sisters with systemic lupus erythematosus-like symptoms. Arthritis Rheum. 24:1255-1260.

13. Hsieh, K. H., C. Y. Lin, and T. C. Lee. 1981. Complete absence of the third component of complement in a patient with repeated infections. Clin. Immunol. Immunopathol. 20:305-312.

14. Pussell, B. A., E. Bourke, M. Nayef, S. Morris, and D. K. Peters. 1980. Complement deficiency and nephritis. Lancet i:675-677.

15. Grace, H. J., G. G. Brereton-Stiles, G. H. Vos, and M. Schonland. 1976. A family with partial and total deficiency of complement C3. S. Afr. Med. J. 50:139-140.

16. Lachmann, P. J., and M. J. Walport. 1987. Deficiency of the effector mechanisms of the immune response and autoimmunity. Ciba Found. Symp. 129:149-171.

17. Kitamura, H., H. Nishimukai, Y. Sano, and K. Nagaki. 1984. Study on C3-like factor in the serum of a C3-deficient subject. Immunology. 51:239-245.

18. Weir, D. M. 1986. Handbook of Experimental Immunology. Blackwell Scientific Publications, Oxford, UK. 39:25-26.

19. Scott, D. M., N. Amos, J. G. P. Sissons, P. J. Lachmann, and D. K. Peters. 1978. The immunoglobulin nature of nephritic factor (NeF). Clin. Exp. Immunol. 32:12-24.

20. Teisberg, P. 1970. High voltage agarose gel electrophoresis in the study of C3 polymorphism. Vox Sang. 19:47-56.

21. Southern, E. M. 1975. Detection of specific sequences among DNA fragments separated by gel electrophoresis. J. Mol. Biol. 98:503-517.

22. de Bruijn, M. H. L., and G. H. Fey. 1985. Human complement component $\mathrm{C} 3: \mathrm{cDNA}$ coding sequence and derived primary structure. Proc. Natl. Acad. Sci. USA. 82:708-712.

23. Feinberg, A. P., and B. Volgelstein. 1984. Addendum to "A technique for radiolabelling DNA restriction endonuclease fragments to high specific activity." Anal. Biochem. 137:266-267.

24. Maniatis, T., E. F. Fritsch, and J. Sambrook. 1982. Molecular Cloning: A Laboratory Manual. Cold Spring Harbor Laboratory, Cold Spring Harbor, NY.

25. Cowan, N. J., P. R. Dobner, E. V. Fuchs, and D. W. Cleveland. 1983. Expression of human $\alpha$-tubulin genes: interspecies conservation of 3' untranslated regions. Mol. Cell. Biol. 3:1738-1745.

26. Frischauf, A. M., H. Lehrach, A. Poustka, and N. E. Murrey.
1983. Lambda replacement vectors carrying polylinker sequences. $J$. Mol. Biol. 170:827-842.

27. Sanger, F., S. Nicklen, and A. R. Coulson. 1977. DNA sequencing with chain terminating inhibitors. Proc. Natl. Acad. Sci. USA. 74:5463-5468.

28. Krug, M. S., and S. L. Berger. 1987. First-strand cDNA synthesis primed with Oligo (dT). Methods Enzymol. 152:316-323.

29. Breathnach, R., C. Benoist, K. O'Hare, F. Gannon, and P. Chambon. 1978. Ovalbumin gene: evidence for a leader sequence in mRNA and DNA sequence at the exon-intron boundaries. Proc. Natl. Acad. Sci. USA. 75:4853-4857.

30. Mount, S. M. 1982. A catalogue of splice junction sequences. Nucleic Acids Res. 10:459-472.

31. Orkin, S. H., H. H. Kazazian Jr., S. E. Antonarakis, S. C. Goff, C. D. Boehm, J. P. Sexton, P. G. Waber, and P. J. V. Giardina. 1982. Linkage of $\beta$-thalassaemia mutations and $\beta$-globin gene polymorphisms with DNA polymorphisms in human $\beta$-globin gene cluster. Nature (Lond.). 296:627-631.

32. Baird, M., C. Driscoll, H. Schreiner, G. Sciarrata, G. Sansone, G. Niazil, F. Ramirez, and A. Bank. 1981. A nucleotide change at a splice junction in the human $\beta$-globin gene is associated with $\beta^{\circ}$-thalassemia. Proc. Natl. Acad. Sci. USA. 78:4218-4221.

33. T. zisman, R., N. J. Proudfoot, M. Shander, and T. Maniatis. 1982. A single-base change at a splice site in a $\beta^{0}$-thalassemic gene causes abnormal RNA splicing. Cell. 29:903-911.

34. DiLella, A. G., J. Marvit, A. S. Lidsky, F. Guttler, and S. L. C. Woo. 1986. Tight linkage between a splicing mutation and a specific DNA haplotype in phenylketonuria. Nature (Lond.). 322:799-803.

35. Grandchamp, B., C. Picat, V. Mignotte, J. H. P. Wilson, K. Te Velde, L. Sandkuyl, P. H. Romeo, M. Goossens, and Y. Nordmann. 1989. Tissue-specific splicing mutation in acute intermittent porphyria. Proc. Natl. Acad. Sci. USA. 86:661-664.

36. Marvit, J., A. G. DiLella, K. Brayton, F. D. Ledley, K. J. H. Robson, and S. L. C. Woo. 1987. GT to AT transition at a splice donor site causes skipping of the preceding exon in phenylketonuria. Nucleic Acids Res. 14:5613-5626.

37. Aebi, M., H. Hornig, and C. Weissmann. 1987. $5^{\prime}$ cleavage site in eukaryotic pre-mRNA splicing is determined by the overall $5^{\prime}$ splice region, not by the conserved 5' gu. Cell. 50:237-246. 